\title{
ORIENTASI PEMIKIRAN ULAMA'N U (Jender dalam Perspektif Ulama Skriptualis dan Subtansialis di NU Cabang Sumenep)
}

\author{
Moh.Jazuli \\ (Sekolah Tinggi A gama Islam al-Karimiyah, Baraji, Gapura, Sumenep, email: \\ Mohjazuli96@yahoo.co.id)
}

\begin{abstract}
A bstrak:
Semenjak akhir abad ke 18 atau awal abad ke -19 Masehi telah tumbuh perjumpaan intensif antara dunia Islam dan dunia Barat. Pada periode ini, kaum Muslim harus menghadapi pilihan yang sangat dilematis, antara keinginan untuk menjunjung tinggi nilai-nilai ajaran Islam dengan kebutuhan mengikuti gagasan-gagasan modern. Ini kemudian melahirkan corak pemikiran skriptualis dan substansialis. Melalui topik jender, kedua corak pemikiran ini juga terjadi di kalangan ulama' NU Cabang Sumenep. Secara ideologis, keduanya berbeda karena metode pemaknaan mereka terhadap teks ajaran Islam juga berbeda. Sedangkan secara sosiologis, keduanya berbeda dalam memandang fenomena sosial yang berkembang. Dalam hal jender, ulama' skriptualis berpegang teguh kepada ketidakbolehan perempuan menjadi pemimpin berdasarkan atas ayat al-Qur'ân dan Hadîts. Sedangkan kalangan ulama' substansialis meneguhkan kebolehan perempuan untuk memegang jabatan publik. Ini didasarkan atas pemaknaan substansial terhadap al-Qur'ân surat al-Nisâ': 34 dan hadîts Nabi.
\end{abstract}

\begin{abstract}
A bstract:
Since the last 18th century or in the beginning of 19th AD has known intensive interaction between Islam and the West. In this period, moslem have to face the dilemma, between the wish to revere the islamic teaching values with the need to follow modern arguments. It causes skriptualis and substansialis thinking. Through the topic of gender, these two thinking also happen in NU ulama' of Sumenep. Ideologically, both of them are different since their method of meaning to islamic teaching also different. While sosiologically, those are different in thinking the developing social phenomenon. In
\end{abstract}


gender, skriptualis ulama' keep thinking of forbidding the women of being the leader based on al-Quran verse and Hadits. On the contrary, substansialis ulama' keep thinking of allowing the women in having the public position based on substantial meaning to al-Qur'ân (al-Nisâ:34) and Hadîts.

Kata-kata Kunci:

Ulama' skriptualis, ulama' substansialis, NU, dan perempuan,

\section{Pendahuluan}

Semenjak akhir abad ke 18 atau awal abad ke -19 Masehi, sejarah Islam memasuki periode modern dengan semangat mengejar ketertinggalan di bidang politik, ekonomi, dan peradaban. Sejarah Islam periode modern ditandai dengan banyak peristiwa yang membedakan dengan periode sebelumnya. Pada periode ini telah tumbuh perjumpaan intensif antara dunia Islam dengan dunia Barat dan melahirkan sejumlah implikasi yang cukup dahsyat bagi perubahan struktur sosial dunia Islam. Sehingga, tidak salah bila Fazlur Rahman menyebutkan bahwa sejarah Islam modern, khususnya mulai abad tersebut, pada hakekatnya merupakan sejarah dampak Barat atas masyarakat Muslim¹.

Bersamaan dengan itu, kaum Muslim harus menghadapi option yang sangat dilematis, antara keinginan untuk menjunjung tinggi nilai-nilai ajaran luhur Islam yang sudah teraktualisasi dalam tradisi kehidupan mereka dengan kebutuhan mengikuti gagasangagasan modern. Berpegang teguh pada warisan tradisi masa lalu dapat berarti mengabadikan subordinasi dan keterbelakangan, sedangkan meninggalkannya sama sekali mungkin akan menghancurkan identitas Islam dan seluruh konstruksi emosional dan intelektual yang telah diwarisi dan dianut selama ini2.

1Lihat Fazlur Rahman, Islam (Chicago: University off Chicago Press, 1979), hlm. 212. W. Montgomery Watt menamakan dampak Barat atas dunia Muslim sebagai "Gelombang Hellenisme ketiga". Simak Watt, Islamic Philosophy and Theology (Edinburgh: Edinburgh University Press, 1972), hlm. 173

2 Lihat Ishtiaq Ahmed, "A bdullahi A hmed An-Na'im on Constitutional and Human Right Issue", dalam Tore Lindholm and Karl Vogs (eds.), Islamic Law Reform and $H$ uman Right: Challengers and Rejoinders (Oslo: Nordic Human Rights Publication, 1993), hlm. 70 
Moh. J azuli

Para pemikir kontemporer berupaya untuk keluar dari dilema ini dengan tetap menjadikan bangunan al-Qur'ân dan Sunnah sebagai sumber normatif dari pemikirannya. ${ }^{3}$ Secara garis besar respon intelektual yang diberikan mereka dapat dipetakan ke dalam dua kelompok4. Pertama, coral pemikiran skriptualis. Corak pemikiran ini lebih menekankan pada aspek legal formal ajaran Islam5, dalam arti bertumpu semata-mata pada teks yang dijadikan sebagai pedoman baku serta kurang memiliki tempat bagi reinterpretasi atas teks-teks tersebut. Kategorisasi halal-haram syarî'ah dapat mendorong skriptualisme, terutama ketika syarî'ah dipandang berlaku universal dan abadi 6 . Pola pemikiran dana gerakan Islam skriptualis yang lahir kemudian adalah revival is atau pra modernisme dan neo revivalis.

Kedua, corak pemikiran substansialis. Pemikiran ini tidak terkungkung oleh nilai-nilai normatif, sehingga lebih leluasa dalam memahami teks secara terbuka dan dinamis. Terma substansi itu sendiri mengandung arti bahwa isi jauh lebih penting daripada bentuk atau label. Karena itu corak pemikiran ini cenderung menafikan hal-hal yang bersifat simbolik; segala yang berkaitan dengan atribut formal ditinggalkan sama sekali7. Pemahaman pada substansi ajaran Islam seperti itu dapat membentuk kapasitas akomodatif terhadap realitas perbedaan dalam hidup ini. Dengan demikian Islam dapat menjadi agama yang dapat bersinergi dengan lingkungannya.

3 Berbicara tentang al-Qur'ân dan sunnah sesungguhnya berbicara tentag interpretasi dan aplikasinya melalui perantara manusia. Lihat Abdullahi Ahmed An-Na'im, Toward an Islamic Toward an Islamic Reformation: Civil Liberties, Human Rights, and International law, N ew York: Syracuse University Press, 1990), hlm. 34. Bandingkan dengan al-Qur'ân surat al-Ankabût (29): 49 yang menggambarkan dirinya sebagai tanda atau makna yang jelas dalam hati dan fikiran umat manusia yang telah diberi ilmu pengetahuan.

4 Secara detail berbagai pemikiran keislaman sebagai respon atas modernitas yang mewakili kedua corak pemikiran tersebut, lihat Khurshid Ahmed, "The Nature of Islamic Resurgence," dalam John L. Esposito (ed.), Voices Resurgent Islam, edisi Indonesia, D inamika Kebangkitan Islam, (Jakarta: Rajawali Press, 1987), hlm. 272-288. 5 N urcholis Madjid, I slam A gama Kemanu siaan, (Jakarta: Paramadina, 1995), hlm. 68 6 Roger Garaudy, Islam Fundamentalis dan Fundamentalis Lainnya, (Bandung: Pustaka, 1993), hlm. 70

7 Alhumani,"Islam di Indonesia dari Skriptualisme ke Substansialisme," R epublika, (29 Juli 1999), hlm. 6 
Beberapa pola pemikiran dan gerakan Islam substansialis yang lahir kemudian adalah pola pemikiran modernisme dan neo modernisme. Modernisme Islam lahir sebagai upaya untuk menerapkan konsep dan struktur Islam ke dalam realitas politik modern yang notabene telah terpengaruh Barat8. Ia dicirikan oleh upayanya untuk merekonstruksi tatanan sosial melalui ijtihâd, didasarkan atas prinsip kebebasan berpikir dan rasionalitas yang terbingkai dalam koridor teks-teks suci 9 . Sedangkan neo-modernisme sebagai pola pemikiran Islam sesungguhnya merupakan sintesis dari pola pikir konservatisme-fundamentalisme dan progressivismemodernisme ${ }^{10}$. Artinya, ia membangun pemikiran progresif yang merupakan tuntutan masyarakat modern dengan tetap berbijak pada tradisi keislaman11.

Dalam konteks Indonesia, berbicara tentang pemikiran substansialis tentu harus melihat kaca benggala masyarakat beragama dan masyarakat bangsa pada umumnya, yaitu Nahdlatul Ulama (NU). Organisasi Islam terbesar di Indonesia ini secara gigih dan konsisten menegaskan dirinya dengan komitmen keislaman inklusif, suatu komitmen ideologis yang bukan saja menghormati dan menghargai perbedaan agama, lebih dari itu menarik komunitas uamat beragama ke dalam perjuangan kemanusiaan yang utuh. Melalui kepeloporan Gus Dur, wacana inklusivisme Islam jauh berkembang dan terinternalisasi ke dalam sikap dan perilaku warga nahdliyin ${ }^{12}$.

Tetapi ketika mendiskusikan pemikiran Islam di NU, sulit untuk tidak mengaitkan individu-individu di dalam organisasi tersebut yang menampakkan keragaman pemikiran atau interpretasi. Inilah yang disebut oleh Uhlin sebagai keunikan organisasional.

8 John L, Esposito dan John L. O. Voll, Islam and Democracy, (Oxford: Oxford University Press, 1996), hlm. 3

9 Lihat Ali E. Hilal Dessouki, Encyclopedia of R eligion, vol. 12, (Baltimore: John Hopkins University Press, 1981), hlm. 15.

${ }^{10}$ Fachri Ali dan Bachtiar Effendi, M erambah Jalan Baru Islam, (Bandung: Mizan, 1986), hlm. 175

11 Greg Barton, “Neo-Modernism: A Vital Synthesis of Tradisionalist and Modernist Islamic Thought in Indonesia,"Studia Islamika, N umber 3 (1995), hlm. 2.

12 Matori Abdul Jalil,"PKB dan Inklusivisme Islam," dalam Marzuki Wahid, et al. (ed)., G eger di "R epublik" N U ; P erebutan W acana, Tafsir Sejarah, Tafsiran M akna, (Jakarta: Kerjasama Kompas dan Lakspesdam NU Jakarta, 1999) 136. 
Moh. J azuli

Karena secara filosofis dan ideologis jarak antara individu yang ada di dalam satu organisasi Islam di Indonesia sering lebih besar daripada jarak antara mereka dengan koleganya di luar orgnisasi itu13.

Jadi meskipun pemikiran substansialis telah menjadi trade mark NU, tidak menutup kemungkinan individu-individu, lebih tepatnya elit ulama, di NU menampakkan pola pemikiran skriptualis. Fenomena tersebut terjadi di kalangan ulama NU cabang Sumenep.

Berdasarkan paradigma pemikiran di atas, penulis tertarik untuk melakukan mengkaji tentang masalah tersebut dalam format judul "Orientasi Pemikiran Ulama' NU (Jender dalam Perspektif Ulama Skriptualis dan Subtansialis di NU Cabang Sumenep).

Sejauh pengamatan penulis, belum ada satu pun penelitian yang memberikan perhatian besar terhadap keberadaan NU, terutama yang berkaitan dengan dinamika aktivitas yang dimainkan dalam setting transformasi sosial, keagamaan maupun politik baik yang bersifat intern ataupun ekstern di Madura, khususnya di lingkungan NU cabang Sumenep. Kajian-kajian yang pernah dilakukan adalah oleh Ali Maschan Musa, Kyai dan Politik (1999) dan Lik Arifin Mansurnoor, Islam in an Indonesian World U lama of M adura (1990). Keduanya memang telah mengadakan kajian tentang ulama di Madura. Kalau Ali Maschan membahas tentang dinamika ulama di Madura melalui BASRA-nya dengan kiprahnya dalam rangka mengembangkan wacana civil society, maka Arifin Mansurnoor di samping dinamika gerakan Islam yang dimainkan oleh Ulama Madura, juga mengupas tentang hubungan antar ulama dalam membangun kerjasama (the ulama's netw ork) melalui jaringan dan jalur kefamilian, sehingga muncul istilah an equal hierarchical station.

Penulis berasumsi bahwa dinamika NU di Madura, khususnya di lingkungan NU cabang Sumenep tidak akan terlepas dari peranan tokoh atau ulama yang punya wewenang untuk menentukan kebijakan langkah NU ke depan. Pandangan-pandangan yang ditumbuhkembangkan oleh masing-masing ulama ternyata beragam yang berarti pula implikasinya terhadap keputusan huku yang ditelorkan secara bersama (al-muqarrarat al-nahdliyah). Akan tetapi

13 Andres Uhlin,, Democracy and Diffusion: Transnational Lesson-D rawing A mong Indonesian Pro-D emocracy A ctors, (Sweden: Lund Political Studies 67, 1995), hlm. 132 
kajian-kajian tersebut belum memberikan topik pembahasan yang detail seputar dinamika NU dan pola pikir ulama yang skriptualis dan substansialis, khususnya di lingkungan NU cabang Sumenep. Dengan demikian, kajian ini dimaksudkan untuk mengisi ruang yang masih kosong tersebut.

Untuk mengkaji lebih mendalam tentang pola pikir ulama skirptualis dan substansialis, kajian ini akan menjawab beberapa persoalan sebagai berikut: Pertama, bagaimana corak pemikiran antara skriptualis dan substansialis dalam perspektif ideologis? Kedua, bagaimana pandangan mereka tentang teks dan kondisi modernitas dalam perspektif sosiologis?

Untuk menghindari bias dalam kajian ini, perlu adanya identifikasi masalah yang menjadi konsentrasi dalam penelitian. Pertama, dalam membahas tentang padangan ulama skriptualis dan substansialis akan dibahas hanya mengenai varian-varian ideologis dan sosiologis yang mempengaruhi pola pikir ulama tersebut. Kedua, dalam menelusuri latarbelakang perbedaan pola pikir antara ulama skriptualis dan substnasialis itu akan dibahas beberapa faktor yang menyebabkan pola pikir mereka. Ketiga, pembahasan tentang pola pikir skriptualis dan substansialis akan diarahkan pada persoalan hukum Islam.

Penelitian ini merupakan penelitian kualitatif dengan menggunakan metode studi kasus. Penelitian kualitatif sebagaimana dikatakan oleh Bodgan dan Biklen adalah penelitian yang menggunakan pengamatan partisipatif dan wawancara mendalam4, serta seperti yang dikatakan, Taylor yang dikutip oleh Moleong, penelitian kualitatif adalah prosedur penelitian yang menghasilkan data deskriptif berupa kata-kata tertulis atau lisan dari pemikiran dan perilaku orang yang diamati15.

Teknik pengumpulan data yang digunakan dalam penelitian ini adalah teknik wawancara secara mendalam dengan para informan yang dipilih secara sengaja (purposive sampling), observasi, dan dokumentasi. Teknik wawancara dilakukan kepada para ulama di

14 Robert C. Bodgan dan knopp Biklen, Qualitative Research for Education, A n Introduction to Theory and M ethod, (Boton: Allyand Boston, Inc, 1982), hlm. xi ${ }^{15}$ Lexy J. Moleong, M etodologi Penelitian Kualitatif, (Bandung: Rosdakarya, 1994), hlm. 3 
Moh. J azuli

NU Cabang Sumenep yang memiliki pandangan skriptualis dan substansialis dan dipilih secara sengaja. Teknik dokumentasi digunakan untuk memperoleh data-data tentang kondisi masyarakat Sumenep yang kemudian ditunjang dengan observasi.

Setelah data dikumpulkan, dilakukan analisis data dengan melalui reduksi data, displai data kesimpulan dan verifikasi16. Pendekatan emik digunakan dalam kajian ini. Pedekatan emik merupakan suatu pendekatan yang berusaha memahami suatu fenomena berangkat dari titik pandang internal17. Pendekatan ini mengharuskan pengkaji untuk melakukan penggalian data secara langsung kepada sumber-sumbernya. Untuk menghasilkan studi yang transferable, diperlukan sebuah posisi yang netral dari pengkaji. Oleh karena itu, peneliti megambil langkah withdrawl atau penarikan diri.

\section{NU Cabang Sumenep: Sejarah dan Tujuan Pendiriannya}

Di Sumenep, NU merupakan organisasi, terutama, bagi kalangan kyai pesantren dan umumnya kaum Muslim tradisional. Pada awal pembentukan cabang-cabang NU, para pendiri NU menggunakan jaringan persahabatan atau santri yang tersebar di berbagai wilayah dan menjadi pengasuh pondok pesantren. Di Sumenep, salah seorang pendiri NU, KH. Hasyim Asy'ari, bersama putranya, KH. Wahid Hasyim, berkunjung ke Pondok Pesantren Annuqayah, Guluk-Guluk dan menunjuk Kyai Ilyas (w. 1959), pengasuh pondok pesantren tersebut, menjadi Rois Syuriyah NU Cabang Sumenep.18 Kyai Ilyas adalah santri kesayangan KH. Hasyim Asy'ari ketika belajar di Pondok Pesantren Tebuireng, Jombang. Kepemimpinan Kyai Ilyas di NU Cabang Sumenep tidak berlangsung lama. Setelah tiga bulan menjabat Rois Syuriyah NU Cabang Sumenep, ia menyerahkan jabatan itu kepada Kyai Abi Syuja', pengasuh Pondok Pesantren Asta Tinggi, Kota Sumenep. Menurut kyai Ilyas, Guluk-Guluk tidak strategis menjadi pusat organisasi NU, karena letaknya yang berada di wilayah pedalaman, yakni $23 \mathrm{~km}$ arah

$16 \mathrm{~S}$. N asution, M etode Penelitian N aturalistik-Kualitatif, (Bandung: Tarsito, 1988), hlm. 126

17 Moleong, M etodologi, hlm. 55

18 Sitrul Arsyi, et al., Satu A bad A nnuqayah: Peran Pendidikan, Politik, dan Pengembangan M asyarakat (Sumenep: PP. A nnuqayah Guluk-Guluk Sumenep, 2000), hlm. 54. 
Barat kota Sumenep. Kepemimpinan NU Sumenep pada jabatan Rois Syuriyah, kemudian, dilanjutkan secara berturut-turut oleh beberapa kyai-pengasuh pondok pesantren, yaitu $\mathrm{KH}$. Usymuni (pengasuh Pondok Pesantren al-Usymuni), KH. Mun'im, KH. Hasyim, KH. Ramdlan Siraj (pengasuh Pondok Pesantren Nurul Islam, Karang Cempaka, Bluto), KH. Ishomuddin AS. (pengasuh Pondok Pesantren Annuqayah Daerah Lubangsa, Guluk-Guluk).

Di jajaran Ketua Umum Tanfidziyah PCNU Sumenep, sejumlah kyai-pengasuh pesantren pernah menduduki jabatan itu. Mereka adalah KH. Taqiyuddin, KH. Tsabit Khazin (pengasuh Pondok Pesantren Annuqayah, Guluk-Guluk), KH. Ramdlan Siraj (Pengasuh Pondok Pesantren Nurul Islam, Bluto), KH. Taufiqurrahman (Pengasuh PP. Mathlabul Ulum, Jambu), KH. Ilyasi Siraj (Pengasuh Pondok Pesantren Nurul Islam, Bluto), dan KH. A bdullah Kholil (Pengasuh Pondok Pesantren Tarate, Sumenep)

Untuk periode 2010-2015, susunan pengurus Pimpinan Cabang NU Sumenep adalah sebagai berikut: (1) Mustasyar: KHA. Warits Ilyas (Pengasuh PP. A nnuqayah Sumenep, Daerah Lubangsa); KH. Fauzi Sirron (Pengasuh PP.AI-Ihsan, Jaddung, Pragaan); Habib Muhammad (Pengasuh PP. Al-Is'af, Kalabaan, Guluk-Guluk); KH. Muqsith Adris (Pengasuh PP. Annuqayah, Guluk-Guluk); KH. Thaifur Aliwafa (Pengasuh PP. Assadat Tanjung A billah, A mbunten); $\mathrm{KH}$. A bdullah Khalil (Pengasuh PP. Al-Usmuni, Pandian); dan KH. Syarqawi; (2) Syuriyah: Rais; KH. Ahmad Basyir AS (Pengasuh PP. A nnuqayah Guluk-Guluk, Daerah Latee); wakil: KH. Taufiqurrahman FM (Pengasuh PP. Mathlabul Ulum, Jambu); KH. Ramdan Siradj (Pengasuh PP. Nurul Islam, Karang Cempaka); Habib Ali Zainal Abidin (Pengasuh Darut Tauhid Assalafiyah, Pajagalan); KH. Aminuddin Jazuli (Pengasuh PP. al-Ihsan, Pragaan); K. Hafidzi Syarbini; KH. Mahfud dz Rahman; KH. Rasyidi (Pengasuh PP. AtTa'awun,Batang-Batang); dan KH. Musyfik; Ust. HM. Badar Bachabazy, Lc. Sedangkan Katib adalah: KH. Zainur Rahman Hamamah (Pengasuh PP. Al-Mukri), KH. Washil Hasyim (Pengasuh PP. Somber Pajung Ganding), K. Imam Hendriadi, KH. Khalilullah, dan K. Chairul A nam (Pengasuh PP. Batu Putih); dan A'wan adalah: KH. A hmad Sa'duddin (Pengasuh PP. Sumber Payung, Bataal Barat); $\mathrm{KH}$. Zakiyuddin; KH. Imam Hasyim (Pengasuh PP. At-Taufiqiyah, Aeng Baja Raja); KH. Ilyasi Siradj, SH. M.Ag (Pengasuh PP. Nurul 
Moh J azuli

Islam Bluto); KH. Syafraji (Pengasuh PP. Usymuni Tarate Sumenep); $\mathrm{KH}$. Ahmad Hammam (Pengasuh PP. Al-Mukri, Prenduan); KH. Zubaidi Ghazali (Pengasuh PP. Sabilun Najah, Banasare); H. Hasan Basri; KH. Baqir Jazuli (Pengasuh PP. Raudlatul Muttaqien, Batu Putih Laok); dan K. A. Munif Zubairi (Pengasuh PP. Nasyaatul Muta'allimin Gapura).

Di jajaran Tanfidziyah: (1) Ketua adalah HA. Pandji Taufiq (PP. Annuqayah Guluk-Guluk) dan wakil ketua adalah Rusly, M.Pd, Nurhadi Moekri, M.Pd, Habib Ja'far, H. Dauri, S. Ag, dan K. Muslih Ali Wafa, S. Ag (PP. Assadat Abillah Ambunten). Sekretaris umum dipercayakan kepada A. Dardiri Zubairi dan wakil sekretaris adalah Moh. Ilyas dan Suhaidi RB.

Dari data di atas, dapat dilihat betapa besar peran kyai pesantren dalam mengembangkan NU, sehingga dapat dikatakan bahwa bahwa penopang utama NU adalah para kyai pesantren. Karenanya, terdapat adagium bahwa NU adalah pesantren besar dan pesantren adalah NU kecil. Eratnya pertalian kedua institusi tersebut tidak bisa dilepaskan dari latar belakang pendiri19 dan pengurus NU yang berasal dari kalangan kyai pesantren, di samping juga tujuan didirikannya NU itu sendiri sebagai wadah bagi usaha menyatukan langkah kyai pesantren dalam mengabdikan diri kepada bangsa, negara, dan umat manusia dalam bidang agama, pendidikan, sosialbudaya, ekonomi, dan usaha-usaha lainnya yang membawa kemaslahatan umat.20

Terdapat hubungan timbal-balik yang bersifat simbiosismutualisme antara NU dan kyai pesantren, yakni bahwa NU menjadi besar berkat dukungan para kyai pesantren, dan kyai pesantren mendapatkan wadah dan saluran perjuangan secara individual maupun kolektif melalui NU. Dalam melakukan misinya tersebut, kyai pesantren memosisikan dirinya pada aras jam'iyah maupun jama'ah. Secara jam'iyah, kyai pesantren melibatkan diri pada berbagai jabatan struktural di organisasi NU. Sedangkan secara jama'ah, kyai pesantren melalui pesantrennya ikut berperan dalam mewujudkan

19 Hasil penelitian Bruinessen memang menunjukkan bahwa NU didirikan oleh sejumlah kyai pesantren tradisional. Lihat Bruinessen, N U , Tradisi, R elasi-relasi Kuasa, Pencarian W acana Baru (Yogyakarta: LkiS, 1994), hlm. 17.

20 Choirul Anam, Pertumbuhan dan Perkembangan N ahdlatul U lama (Surabaya: Jatayu Sala, 1985), hlm. 19. 
visi dan misi NU serta melakukan penguatan pada masyarakat akar rumput sebagai pengikut setia kyai dan NU.

\section{Orientasi Pemikiran Skriptualis dan Substansialis tentang Jender di Kalangan U lama N U Cabang Sumenep}

Orientasi pemikiran yang ditampakkan oleh kedua corak pemikiran antara skriptualis dan substansialis sangatlah berbeda. Pertama, skriptualis cenderung memperlakukan ortodoksi sebagai tujuan. Realitas haruslah sesuai dengan teks ajaran. A pabila terjadi konflik antara realitas dengan teks ajaran, maka tugas kaum agamawan adalah selekas mungkin melakukan penaklukan terhadap realitas itu terhadap ajaran. Tugas menaklukkan realitas yang menyeleweng itulah yang dikenal dengan misi amar ma'rûf nahy munkar21. Menurut Masdar F. Mas'udi, kategori tadi melahirkan masyarakat dengan semangat ortodoksi tinggi, bahkan menjadi sangat idealis. Akan tetapi ketika harus melakukan perawatan terhadap teks yang jelas-jelas berbeda dengan ketika teks ajaran itu diturunkan, mereka seringkali naif. Kenaifan itulah yang diduga telah memicu ekstrimisme pemikiran. Sejarah umat Islam telah banyak yang mempersaksikan peristiwa-peristiwa memilukan akibat pola pemahaman keagamaan seperti itu.

Kedua, adalah pola pemikiran realis yang concern-nya memaklumi dan menerima realitas dengan mempertimbangkan substansi dari teks ajaran, walaupun untuk itu ajaran dalam teks boleh jadi digugat atau dimodifikasi22. Tipologi pemahaman keagamaan seperti itu pada masa lalu diwakili oleh kelompok Mu'tazilah yang intelektualistik. Dengan tesisnya yang kontroversial bahwa al-Qur'ân itu makhluk, maka sebenarnya mereka ingin mengatakan bahwa Mu'tazilah dan pengikutnya mencari legitimasi jika pada suatu saat mereka harus menggugat dan membuang begitu saja apa yang dikatakan oleh teks al-Qur'ân. Kepercayaan mereka terhadap nalar manusia telah memaksa mereka melihat wahyu tidak

\footnotetext{
21 Lihat Zainal A rifin Thaha,"Pemikiran skriptualis dan realis yang menjadi landasan pemikiran teologis gerakan sosial NU" dalam Membangun Budaya Kerakyatan, (Yogyakarta: Titian Ilahi Press, 1997), hlm. 175

22 Ibid., hlm. 175
} 
Moh. J azuli

bertentangan dengan apa yang menjadi keputusan manusia yang hadir dalam bentuk realitas konseptual maupun sosial23.

Nampaknya kategorisasi semacam itu berlaku pula di kalangan ulama NU. Satu sisi NU berada pada garis keras dalam merespon perkembangan. Sedangkan pada sisi yang lain terdapat tarikantarikan yang begitu kuat untuk bersikap realistik. Salah satu contoh persoalan yang diajukan oleh penulis kepada para kyai (ulama) di lingkungan NU cabang Sumenep adalah persoalan gender yang sempat aktual dan sempat terjadi polemik di kalangan ulama NU24. Persoalan yang diajukan, berangkat dari hadîts Nabi Muhammad saw. tentang jender, ${ }^{25}$ yang berbunyi:

"Tidak akan beruntung kaum yang mengangkat seorang perempuan sebagai pemimpin mereka" 26 .

Interpretasi para ulama yang ada di lingkungan NU Cabang Sumenep mengenai maksud hadîts di atas sangat variatif. Ada yang berpendapat bahwa hadîts tersebut sebagai landasan hukum ketidakbolehan perempuan menjadi pemimpin. Kelompok itulah yang kemudian menjadi cikal bakal lahirnya ulama skriptualis. Di pihak lain, ada yang berpendapat bahwa substansi hadîts tersebut harus disesuaikan dengan konteksnya. Kelompok inilah yang kemudian melahirakan ulama substansialis.

\section{A. Ulama Skriptualis di N U Cabang Sumenep}

Pola pikir yang berkembang di kalangan ulama NU Cabang Sumenep masih banyak yang beranggapan bahwa sumber ajaran Islam adalah berasal dari teks suci baik itu berupa al-Qur'ân maupun hadîts. Karenanya, ketika teks itu dianggap sebagai sumber ajaran, maka interpretasi apapun harus sejalan dengan

\footnotetext{
23 Ibid., hlm. 176

24 Di NU sendiri, para ulama yang mengetahui seluk beluk ketatanegaraan pada umumnya cenderung membolehkan perempuan menjadi presiden, karena berbeda dengan pemimpin tunggal yang menguasai eksekutif, legislatif dan yudikatif (al Imâm al-a'zhâm). Lihat A. Hasyim Muzadi, $N$ ahdlatul U lama di T engah A genda Persoalan Bangsa (Jakarta: PT. Logos Wacana IImu, 1999), hlm. 78

25 Lihat Mansour Fakih, M embincang Feminisme Diskursus Gender Perspektif Islam (Surabaya: Risalah Gusti, 1996), hlm. 71-77. Juga Lihat A sghar Ali Engineer, $\mathrm{H}$ ak-H ak Perempuan Dalam Islam, (Jakarta: LSPPA, 1994), hlm. 106. Bandingkan juga dengan Fatimah Mernisi dan Riffat Hasan, Setara di Hadapan Allah (Yogyakarta: Pustaka Pelajar), hIm. 179-184

26 Lihat al-Bukhârî, Sahîh al-Bukhârî, Juz III (Beyrut; Dâr al-Fikr, 1990), hlm. 90-91.
} 
teks yang ada. Pandangan ini dikemukakan oleh $\mathrm{KH}$. A bd Basith AS, yang mengatakan bahwa teks ajaran yang termaktub di dalam al-Qur'ân maupun hadîts tidak perlu diinterpretasikan lain selain yang termaktub di dalamnya. Di samping itu, ia harus disesuaikan dengan penafsiran para ulama terdahulu. Kesan yang muncul pada waktu itu adalah bahwa teks hadîts adalah sumber ajaran Islam yang tidak boleh ada pemaknaan lain selain yang telah dijelaskan oleh para ulama salaf terdahulu. Karena teks itu adalah teks suci. Beliau menambahkan bahwa kalau pun ada pemaknaan lain, juga jangan sampai meninggalkan makna yang tersurat di dalam teks itu. ${ }^{27}$ Pola pikir yang dikembangkan olehnya mungkin disebabkan latarbelakang pendidikannya yang berasal dari Timur Tengah yang oleh sebagian orang cenderung skriptual dan tekstual.

Senada dengan pandangan di atas, $\mathrm{KH}$. Taufiqurrahman menegaskan bahwa tidak perlu bahkan tidak boleh ada interpretasi lain yang seakan menyimpang dari pemahaman ulama-ulama salaf yang telah banyak tertuang dalam kitab-kitab klasik ${ }^{28}$. Oleh karena itu, menurut KHA. Basyir AS, ketika hadîts di atas diajukan kepada mereka, proses pemahamannya tetap pada konsep awal sesuai dengan bunyi teks bahwa apa pun alasannya, suatu kaum tidak akan pernah beruntung apabila dipimpin oleh seorang perempuan.29 Bahkan beliau menegaskan bahwa apa pun tujuan dan cita-cita suatu kaum tidak akan pernah tercapai selama yang memimpin mereka adalah perempuan atau seorang perempuan. Beliau mencontohkan ketika terjadi perang jamal antara Sayyidinâ Alî r.a. dengan Aisyah (yang pada waktu itu menjadi panglima perangnya). Ternyata akhir dari pertempuran itu dimenangkan oleh pihak Ali dan Aisyah kemudian dideportasi untuk dikembalikan ke Madinah. Para ulama berkesimpulan bahwa perempuan kalau

27 Wawancara dengan K.H. A bd. Basith AS, (Mustasyar NU Cabang Sumenep) pada 9 September 2010.

28 Wawancara dengan K.H. Thaifur Ali Wafa (Mustasyar NU Cabang Sumenep dan (Pengasuh PP. Assadat Tanjung A billah, A mbunten) pada 8 September 2010.

29 Wawancara dengan K.H.A. Basyir AS, (Rois Syuriyah NU Cabang Sumenep dan Pengasuh PP. An-Nuqayah Daerah Latee Guluk-Guluk Sumenep) pada 31 Agustus 2010. 
Moh. J azuli

terlalu maju ke depan, maka tujuan dan cita-cita apapun seringkali kandas. Hal tersebut dikarenakan dari seorang perempuan itu terlalu banyak kekurangannya baik fisik maupun mental.

Pandangan ini juga didukung oleh K.H. Ishamuddin As yang menegaskan bahwa apa pun yang menjadi pemaknaan kita terhadap sebuah teks, haruslah dicari rujukannya sesuai dengan interpretasi dan penafsiran para ulama terdahulu yang sudah banyak ditulis di dalam kitab-kitab klasik. Jadi, tinggal kita membaca dan memahaminya saja. Kemudian beliau menegaskan bahwa selama persoalan itu masih dalam kategori persoalan ikhtilâf di kalangan ulama, maka keputusan NU secara jam'iyyah tidak pernah membberikan keputusan yang sepihak hitam atau putih. Semuanya diserahkan kepada pemahaman masing-masing sesuai dengan keyakinan yang ada.

Keadaan sebaliknya berlaku apabila dalam kondisi darurat. $\mathrm{KH}$. Ghazali berpendapat bahwa persoalan perempuan menjadi (pemimpin) presiden dalam konteks Indonesia adalah persoalan yang darurat. Jadi kondisi kita sudah memasuki kondisi terpaksa. Karena itu, maka dalam perspektif figh dibolehkan bagi seeorang perempuan memimpin suatu kaum.30 Akan tetapi menurut K.H.A. Warits Ilyas bahwa kondisi yang terjadi di Indonesia belum sampai pada kondisi darurat. Sebab naiknya Mega, misalnya, menjadi presiden bukan karena terpaksa dan tidak ada kader lain yang lebih pantas. Melainkan hal tersebut disebabkan tuntutan konstitusional yang mengatur ketatanegaraan. Jadi, ketika presiden berhalangan tetap atau diberhentikan, maka secara otomatis wakil presiden mengganti posisi itu sampai habis masa jabatannya. ${ }^{31}$

Di samping itu, secara umum para ulamâ' di atas memiliki landasan ideologis berupa firman Allâh swt. dalam QS. AI-

30 Wawancara dengan K.H. Ghazali (A'wan NU Cabang Sumenep) pada 30 Agustus 2010.

31 Wawancara dengan K.H.A. Warits Ilyas (Mustasyar NU Cabang Sumenep) dan Pengasuh PP. An-N uqayah Daerah Lubangsa Sumenep) pada 31 A gustus 2010). 
Nisâ'(4): 34,32 QS. al-Baqarah (2): 228,33 dan QS. al-Ahzab (26): 33,34 yang kesemuanya menyatakan subordinasi perempuan di bawah laki-laki35. Alasan yang dikemukakan mereka juga berdasar pada justifikasi Nabi saw bahwa perempuan itu lemah secara emosional dan kurang dari segi agamanya36.

Pada akhirnya mereka beranggapan bahwa syarî'at Islam tidak membolehkan perempuan memperoleh hak-hak politik secara umum. Karena di situ ada tuntutan pendapat dan keteguhan yang tidak dapat dilakukan oleh kaum perempuan ${ }^{37}$.

Secara sosiologis, menurut mereka, ketidakbolehan perempuan untuk berkiprah dalam masalah-masalah publik, salah satu alasan kuat adalah karena kondisi sosial yang masih belum dapat menerima kenyataan bahwa perempuan juga berpartisipasi di bidang sosial kemasyarakatan yang masih didominasi oleh kaum laki-laki, sebagaimana pada masa Nabi dan sahabat. Ketidaklumrahan semacam itulah yang kemudian melahirkan pemikiran di kalangan ulama untuk tidak membolehkan bagi perempuan ikut terjun ke dunia luar (selain urusan keluarga), termasuk dunia politik. Karena bagaimana pun hal-hal yang belum lumrah di sebuah komunitas (Muslim pada

\footnotetext{
32 "Kaum laki-laki itu adalah pemimpin bagi kaum perempuan. Oleh karena itu Allah telah melebihkan sebagian mereka (laki-laki) atas sebagian yang lain (perempuan) dan karena mereka (laki-laki) telah menafkahkan sebagian harta mereka".

33 "D an para wanita mempunyai hak yang seimbang dengan kewajibannya menurut cara yang makruf. A kan tetapi para suami mempunyai satu tingkatan lebih daripada istrin ya".

34 "D an hendaklah kamu tetap di rumahmu, dan janganlah kamu berhias dan bertingkah laku seperti orang-orang jahiliyah yang dahulu".

35 Wawancara dengan K.H. Abdullah Khalil (Mustasyar dan mantan Ketua Tanfidziyah NU Cabang Sumenep) pada 7 September 2010. Beliau tetap berpandangan bahwa perempuan itu berada di bawah tanggungjawab laki-laki. Walaupun ayat tersebut dimaksudkan pada persoalan domistik keluarga, akan tetapi analoginya adalah terlebih lagi pada persoalan publik yang menyangkut persoalan orang banyak. Jadi, perempuan tidak perlu berada pada posisi terdepan dan kalau pun mau ikut berkiprah dalam persoalan publik di luar runga lingkup keluarga, posisinya tetap berada di second line.

36 Lihat dalam mukhtasar Imâm Bukhârî.

37 Lihat Muhammad Anis Qasim Ja'far, Perempuan dan K ekuasaan, alih bahasa Irwan Kurniawan dan Abu Muhammad, (Bandung: Zaman, 1998), hlm. 41-44. Bandingkan dengan Muhammad Thalib, 17 Alasan $M$ embenarkan Wanita M enjadi Pemimpin dan A nalisisnya, (Bandung: Irsyad Baitus Salam, 2001), hlm. 52-61.
} 
Moh. J azuli

umumnya), lalu dilakukan, akan berimplikasi negatif bahkan dapat memicu timbulnya fitnah di kalangan masyarakat. A pabila hal itu terjadi, berarti tujuan dibentuknya hukum Islam tidak tercapai. Oleh karena itu, mencegah hal-hal yang akan mengarah kepada kejelekan dan kerusakan dalam struktur sosial adalah dianjurkan yang dalam istilah ushul figh disebut dengan "sadd aldzarî'ah".

\section{B. Ulama Substansialis di N U Cabang Sumenep}

Sebagaimana telah dijelaskan pada bagian sebelumnya, bahwa pemikiran substansialis38 lebih menekankan pada esensi atau substansi daria sebuah teks dengan cara juga melihat realitas yang berkembang, sehingga dengan demikian survivalitas ajaran teks senantiasa tetap berlaku seiring dengan perkembangan waktu dan tempat39.

Oleh karena itu, ketika ada persoalan gender yang berasal dari teks hadîts Nabi saw sebagian ulama di NU cabang Sumenep, seperti K.H. Safraji dan K. Ilyasi Siraj mempunyai pemaknaan yang sunstansial 40 . Pertama, mereka menilai dari akar historis bahwa hadîts tersebut dilihat dari latar belakang sejarahnya. Kedua, hadîts tersebut juga harus dilihat konteksnya bahwa sebab datang atau asbab al wurud hadîts tersebut adalah kasuistik dan reaktif terhadap penghinaan raja Kisra. Ketiga,

\footnotetext{
38 Pemikiran tersebut selalu berusaha untuk melakukan pendekatan-pendekatan yang bijaksana, terutama dalam bidang figh. Landasan dan pijakan kelompok tersebut adalah sebuah representasi pemikiran yang hadir tepat pada waktunya. Bahkan pemikiran itulah yangg lantang menyuarakan ide-ide rekonstruksi wacana figh. Sehingga dengan demikian kehadiran Islam akan nampak terbuka, bebas dan tidak kaku berhadapan dengan persoalan-persoalan modernitas. Lihat Tolak Imam Putera,"Pembaharuan Fikih di Mesir; Dari Kritik Formalisme Teks Menuju Kontekstualisasi", T ashwirul A fkar, No. 8 (2000), hlm. 46

39 Ulama fiqh mengistilahkan dengan ungkapan Taghayyur al-ahkâm bi taghayyur alamkân wa al-azmân

40 Wawancara dengan K.H. Safraji (A'wan NU Cabang Sumenep dan pengasuh PP. Usymuni Tarate Sumenep) pada tanggal 8 September 2010 dan K. Ilyasi Siraj, MA (A'wan dan mantan Ketua Tanfidziyah NU Cabang Sumenep), tanggal 26 Oktober 2010. Mereka merepresentasikan pemikiran substansialis di kalangan ulama NU Cabang Sumenep yang mempunyai asumsi bahwa ketika teks ajaran itu hadir, maka harus dilihat dari substansi yang terkandung di dalamnya. Sehingga dengan demikian, kehadirannya akan mudah dapat diterima oleh realitas sosial yang kompleks dan penuh dengan tuntutan modernitas.
} 
bahwa pada saat ini (dalam konteks Indonesia) sistem ketatanegaraan berbeda dengan masa dahulu yang bersifat kerajaan (raja adalah penguasa tunggal yang punya otoritas penuh). Sedangkan sekarang, seorang presiden itu hanya berkuasa di bidang eksekutif. Keempat, substansi dari hadîts tersebut bukan persoalan gender yang membedakan antara jenis laki-laki dan perempuan. A kan tetapi stressing-nya lebih kepada profesionalisme dan kompetensi seseorang. Sebagaimana firman Allâh swt. yang mengisahkan kesuksesan dan kejayaan negeri Saba' yang dipimpin oleh seorang perempuan cantik jelita yang bernama Ratu Balqis ${ }^{41}$.

Menanggapi firman Allâh surat al-Nisâ' (4): 34,42 mereka menilai bahwa sebenarnya fokus ayat di atas adalah persoalan domistik keluarga yang memposisikan seorang suami sebagai kepala rumah tangga dan sang istri sebagai pendampingnya. Jadi, konteks ayat tersebut lebih kepada persoalan keluarga, bukan pada persoalan publik. Sebab, hal-hal yang menyangkut urusan publik tidak menitikberatkan kepada faktor jenis kelamin, melainkan kemampuan, kompetensi dan profesionalisme yang menjadi acuan utama. Kalau sorang perempuan dianggap mampu dan memiliki kapasitas untuk memimpin, kenapa tidak?

Oleh karena itu, perempuan mempunyai hak untuk menikmati hak-hak politik sama dengan laki-laki. Ia mempunyai hak untuk menduduki jabatan politik di tingkat mana pun. Mereka berpendapat bahwa penting adanya persamaan hak antara laki-laki dan perempuan dalam menggunakan hak-hak politik. Karena kepentingan umum dan praktik demokrasi menghendaki hal tersebut. Perempuan merupakan bagian dari masyarakat. Mereka mempunyai kepentingan yang sama dengan kepentingan laki-laki. Maka, persamaan diantara keduanya harus direal isasikan dalam mengatur urusan-urusan umum negara. $\mathrm{Hal}$ tersebut tisak dapat terlaksana kecuali kalau perempuan dapat menggunakan hak politiknya secara sempurna. Kekuarangan

41 Lihat dalam QS. al-Naml (27): 32-33.

42 "Kaum laki-laki itu adalah pemimpin bagi akum wanita. Oleh karena itu Allah telah melebihkan sebagian mereka (laki-laki) atas sebagian yang lain (wanita) dan karena mereka (laki-laki) telah menafkahkan sebagian harta mereka". 
Moh. J azuli

yang ada pada perempuan adalah hal yang manusiawi, sebab laki-laki juga punya kekurangan.

Sesungguhnya keikutsertaan perempuan dalam hal-hal politik adalah masalah keadilan, karena prinsip demokrasi memberikan kepada setiap orang kesempatan untuk berpolitik untuk menjaga dan membela kepribadiannya. Perempuan adalah bagian dari umat yang harus diajak musyawarah dan mempunyai hak yang sama dengan laki-laki dalam persoalan ini. Pendapat di atas berdasarkan ayat:

"Dia (Ratu Balqis) berkata: Hai para pembesar, berilah aku pertimbangan dalam urusanku ini. A ku tidak pernah memutuskan suatu perkara sebelum kamu berada dalam majelisku. M ereka menjawab: Kita adalah orang-orang yang memiliki kekuatan dan keberanian yang sangat (dalam peperangan). Sedangkan keputusan berada di tanganmu. M aka pertimbangkanlah apa yang akan kamu perintahkan".

Ayat di atas menjelaskan bahwa perempuan mampu mengemukakan pendapat yang benar, berpartisipasi dalam persoalan politik serta menanggung tanggungjawab yang sangat besar.

Di samping itu ada suatu peristiwa yang mengisahkan bahwa suatu saat kaum perempuan berbai'at kepada Rasulullah saw sebagaimana laki-laki berbai'at kepadanya. Sebagaimana firman Allah swt::

"Hai Nabi, apabila datang kepadamu perempuan-perempuan yang beriman untuk mengadakan perjanjian setia, bahwa mereka tidak akan mempersekutukan sesuatupun dengan Allah, tidak akan mencuri, tidak akan berzina, tidak akan membunuh anak-anaknya, tidak akan berbuat dusta yang mereka ada-adakan antara tangan dan kaki mereka, dan tidak akan mendurhakaimu dalam urusan yang baik, maka terimalah janji setia mereka dan mohonkanlah ampunan kepada Allah untuk mereka. Sesungguhnya Allah M aha Pengampun lagi M aha Penyayang (QS. A I M umtahanah: 12).

Sejalan dengan ayat di atas delegasi Ansor membai'at Nabi pada bai'at Aqabah kedua. Kaum perempuan telah bersumpah terhadap diri mereka sendiri di dalam bai'at itu untuk membela dan melindungi Islam. Ini menunjukkan 
bolehnya partisipasi perempuan dalam berbagai hak politik. Sebab bai'at ini dianggap sebagai kegiatan politik.

Rasulullah saw. membolehkan perempuan mewakili kaum Muslim dan memberikan jaminan atas nama mereka. Rasulullah saw telah menerima Ummu Hani' terhadap seorang kafir pada hari penaklukan kota Makkah. Rasulullah saw berkat kepadanya:"Kami melindungi orang yang dilindungi Ummu Hanik"43.

Perempuan punya hak untuk menjadi Imam Masjid seperti laki-laki. Dalam hadîts lain beliau bersabda:"Jika perempuan (istri) meminta idzin kepada siapa saja dari kalian, maka jangnalah kalian melarangnya" 44.

Masjid merupakan suatu tempat (sehubungan keberadaannya sebagai rumah ibadah) berkumpul kaum Muslim dan bermusyawarah tentang urusan mereka. Mengingat Islam membolehkan perempuan mendatangi masjid, maka perempuan pun dapat memberikan sumbangan pemikiran dalam musyawarah-musyawarah yang diselenggarakan di dalam masjid.

Ada pendapat lain yang menganggap bahwa hak politik bagi perempuan itu tidak ada kaitannya dengan agama atau undang-undang, melainkan merupakan masalah sosial dan politik saja45. Pencetus pendapat itu berkata: "Karena tidak ada hukum syarî'at yang melarang perempuan menggunakan hakhak politik, maka keliru berupaya memecahkan masalah ini dengan menganggapnya sebagai masalah agama atau figh" 46.

\footnotetext{
43 Lihat Muhammad Anis Qasim, Perempuan dan K kuasaan, terj. Irwan Kurniawan dan A bu M uhammad (Bandung: Zaman, 1998), hlm. 63

44 Ibid., hlm. 63

45 Salim Ali Bahnasawi, Wawancara Sistem Politik Islam, Jakarta: Pustaka al Kautsar, 1997), hlm. 293

$46 \mathrm{Ja}$ 'far, P erempuan dan K ekuasaan, hlm. 65. Referensi yang sering digunakan untuk mempertahankan status quo dan melegalkan pola hidup patriarkhi adalah kitab tafsir bahwa laki-laki dianggap sebagai jenis kelamin utama, sedangkan perempuan dianggap sebagai jenis kelamin kedua. Mungkin yang perlu dilakukan adalah bagaimana reinterpretasi al-Qur'ân dapat dianggap sesuatu yang on going process yang harus dilakukan setiap saat seiring dengan perubahan sosial. Kemudian bagaimana mengartikulasikan sejumlah ayat yang dinilai bias gender ke dalam
} 
Moh. J azuli

Pencetus pendapat itu memandang bahwa hal tersebut adalah masalah sosial politik. Sehingga harus dicari solusinya berdasarkan kondisi sosial, politik, ekonomi, pendapat umum yang berlaku pada masa dan tempat tertentu serta prinsipprinsip keadilan. Selain itu, harus kita hilangkan dari syarî'at Islam atau hukum positif segala kendala yang merintangi jalan yang dibentuk kondisi lingkungan dan tuntutan kepentingan umum. Pendangan tersebut dipegang oleh seorang ahli hukum Dr. Abdul Hamid Mutawalli dalam bukunya 'M abâdi' al-hukm fî al-Islâm" berdasarkan pada pemikiran bahwa logika memainkan peran dalam menafsirkan prinsip-prinsip hukum khusus ${ }^{47}$.

Pandangan-pandangan tadi sejalan dengan pemikiran sebagaian ulama NU Cabang Sumenep yang punya pola pemikiran substansialis dan kontekstualis. Misalnya, K. Safraji dan K. Ilyasi yang keduanya berpendapat bahwa ketika teks ajaran itu hadir, harus dicari substansinya apa, kemudian disesuaikan dengan konteks yang sedang berkembang.

Dalam perspektif sosiologis, mereka memandang agama sebagai sistem kepercayaan yang diwujudkan dalam perilaku sosial tertentu. la berkaitan dengan pengalaman manusia, baik sebagai individu maupun kelompok. Sehingga, setiap perilaku yang diperankannya akan terkait dengan keyakinan dari ajaran agama yang dianutnya. Perilaku individu dan sosial digerakkan oleh kekuatan dari dalam yang didasarkan pada nilai-nilai ajaran agama yang menginternalisasi sebelumnya. Karena itu, Wach lebih jauh beranggapan bahwa keagamaan yang bersifat subyektif, dapat diobyektifkan dalam pelbagai macam ungkapan, dan ungkapan-ungkapan tersebut mempunyai struktur yang dapat dipahami.

C.Y. Glock dan R. Stark, yang dikutip oleh Dadang Kahmad,48 menyebutkan lima dimensi beragama. Pertama, dimensi keyakinan. Dimensi ini berisikan pengharapan sambil berpegang teguh pada teologis tertentu. Kedua, dimensi praktik

masyarakat kita yang melakukan penelaahan ulang secara kritis terhadap ayat-ayat tersebut.

47 Bahnasawi, W aw an cara Sistem, hlm. 294.

48 Lihat Dadang Kahmad, Sosiologi A gama, (Bandung: PT. Remaja Rosdakarya: 2000), hlm. 53 
agama yang meliputi prilaku simbolik dari makna-makna keagamaan yang terkandung di dalamnya. Ketiga, dimensi pengalaman keagamaan merujuk pada seluruh keterlibatan subjektif dan individual dengan hal-hal yang suci darai suatu agama. Keempat, dimensi pengetahuan tentang keyakinan ritus, kitab suci, dan tradisi. Kelima, dimensi konsekuensi yang mengacu pada indentifikasi akibat-akibat keyakinan, praktik, pengalaman, dan pengetahuan seseorang darai hari ke hari.

Ketika mengungkap hubungan interdependensi antar agama dan masyarakat, Wach menunjukkan adanya pengaruh timbal balik antara keduafaktor tersebut. Pertama, pengaruh agama terhadap masyarakat, seperti yang terlihat dalam pembentukan, pengembangan dan penentuan kelompok keagamaan spesifik yang baru. Kedua, pengaruh masyarakat terhdap agama. Dalam hal ini, Wach memusatkan perhatiannya pada faktor-faktor sosial yang memberikan nuansa dan keragaman perasaan dan sikap keagamaan yang terdapat dalam suatu lingkungan atau kelompok sosial tertentu49.

Dengan demikian, dimensi esotorik dari suatua agama atau kepercayaan pada dasarnya tidak berdiri sendiri, tetapi berkaitan dengan dimensi lain di luar dirinya. Selain dibentuk oleh substansi ajarannya, dimensi ini juga dipengaruhi oleh struktur sosial dimana suatu keyakinan itu dimanifestasikan oleh para pemeluknya, sehingga dalam konteks tertentu, di satu sisi agama juga dapat berdaptasi dan pada sisi yang berbeda dapat berfungsi sebagai alat legitimasi dari proses perubahan yang terjadi di sekitar kehidupan para pemeluknya.

Sejalan dengan perspektif itu, dapat dikatakan bahwa agama merupakan salah satu bentuk legitimasi yang paling efektif. Agama merupakan semesta simbolik yang memberi makna pada kehidupan manusia dan memberikan penjelasan yang paling komprehensif tentang seluruh realitas. Agama merupakan naungan; sakral yang melindungi menusia dari situasi kekacauan (chaos). Bagi para penganutanya, agama berisikan ajaran-ajaran mengenai kebenaran tertinggi (summun bonum) dan mutlak tentang eksistensi manusia dan petunjuk-

49 lbid., hlm. 54 
Moh. J azuli

petunjuk untuk hidup selamat di dunia dan akherat, yaitu sebagai manusia yang bertakwa kepada Tuhannya, beradab dan manusiawi, yang berbeda dari cara-cara hidup hewan atau makhluk lainnya. Sebagai sistem keyakinan, agama bisa menjadi bagian dan inti dari sistem nilai yang ada dalam kebudayaan dari masyarakat, dan menjadi pendorong atau penggerak serta pengontrol bagi tindakan anggota masyarakat tertnetu untuk tetap berjalan sesuai dengan nilai-nilai kebudayaan dan ajaran agamanya. Ketka pengaruh ajaran agama sangat kuat terhadap sistem nilai dari kebudayaan masyarakat yang bersangkutan, maka sistem nilai kebudayaan itu terwujud sebagai simbol suci yang maknanya bersumber pada ajaran agama menjadi kerangka acuannya50.

Dalam keadaan demikian, secara langsung maupun tidak langsung, etos yang menjadi pedoman dari eksistensi dan kegiatan berbagai pranata yang ada dalam masyarakat (keluarga, ekonomi, politik, dan pendidikan), dipengaruhi, digerakkan, dan diarahkan oleh berbagai sistem nilai yang sumbernya adalah agama yang dianutnya dan terwujud dalam kegiatan oleh simbol-simbol suci. Keyakinan agama yang sifatnya pribadi dan individual bisa berupa tindakan kelompok. Keyakina itu menjadi sosial disebabkan oleh hakekat agama itu sendiri yang salah satu ajarannya adalah hidup dalam kebersamaan dengan orang lain. Kegiatan keagamaan dalam bentuk berjamaah, kongresisasi atau upacara ritual dalam kelompok amat penting dalam setiap agama51.

Dalam kehidupan berkelompok atau bermasyarakat itulah, tradisi keagamaan yang dimiliki oleh individu akan menjadi kumulatif dan kohesif yang menyatukan keanekaragaman interpretasi dan sistem keyakinan keagamaan, penyatuan keanekaragaman itu dapat terjadi karema pada hakekatnya dala setiap kehidupan berkelompok terdapat pola interaksi yang melibatkan dua irang atau lebih. Dari pola tersebut para anggotanya secara bersama memiliki satu tujuan atau beberapa tujuan utama yang diwujudkan sebagai tidanakn

50 lbid., 63

51 lbid., 64 
berpola. Hal itu dimungkinkan karena kegitan kelompok tersebut terarah atau terpimpin berdasarkan norma yang disepakati bersama sebagai wujud dari kehidupan berkelompok. Adanya norma itu sebenarnya juga merupakan sistem status yang masing-masing mempunyai kekuasaan dan kewenangan serta prestise yang berbeda sesuai dengan tujuan utama yang ingin dicapai oleh kelompok tersebut 52 .

Oleh karena itu, ketika agama (teks ajaran) dipahami melalui perspektif sosiologis, implikasinya akan semakin baik dan merata bagi seluruh lapisan masyarakat. Yang terpenting lagi bahwa agama itu akan lebih nampak humanis dari aspek kemanusiaan dan lebih akomodatif terhdap berbgaia macam tuntutan dari aspek managerial. Islam hadir akan lebih memberikan kedamaian kepada seluruh umat manusia dan ajarannya akan lebih membumi (meminjam sitilah Quraish Shihab dalam bukunya Membumikan AI Quran) karena lebih mudah untuk diimplementasikan dalam kehidupan tanpa merugikan pihak-pihak tertentu.

Demikian juga persoalan pemahaman terhadap teks hadîts di atas, kalau dipahami secara tekstual melalui perspektif teologis, maka implikasinya akan menimbulkan kecemburuan sosial. Sebab secara emosional para perempuan yang merasa punya kompetensi (ahliyah) untuk ikut berkiprah dalam persoalan publik, kemudian hasrat mereka terbentur dengan landasan teks hadith tersebut, tentunya secara langsung maupun tidak mereka akan memberontak.

Sebagain ulama di NU Cabang Sumenep melihat fenomena yang berkembang telah menunjukkan adanya kemajuan peradaban dan kebudayaan sebagai gejala sosial di lingkungan masyarakat Sumenep. Dalam perspektif sosiologis itulah, mereka menilai bahwa kiprah kaum Hawa di bidang publik sudah tidak perlu dipersoalkan lagi dengan catatan bahwa kiprah itu tidak sampai melampaui batas-batas kewajaran dan kodrat sebagai seorang perempuan. Sebab bagaimana pun, kewajiban sorang perempuan juga yang terpenting adalah aktifitasnya dalam rumah tangga dalam rangka memelihara dan

52 Ibid. 
Moh. J azuli

mengalirkan kasih sayang kepada anak cucunya di samping juga mendampingi sang suamii dalam uurusan domestik rumah tangga. Hal tersebut dijelaskan secara gamblang oleh K. Safraji di kediamannya, Pondok Pesantren Aqidah Utsmuni Tarate Sumenep.

Melihat pola pemikiran yang skriptual dan substansial di kalangan ulama NU Cabang Sumenep berkenaan dengan pemahaman terhadap teks hadîts di atas, penulis ingin mencoba memberikan sedikit ulasan sehubungan dengan wacama yang berkembang saat ini. Menurut hemat penulis bahwa justifikasi tentang boleh tidaknya seorang perempuan berkiprah di bidang publik (termasuk menjadi presiden) berdasarkan pemaknaan terhadap hadîts di atas adalah sudah termasuk dalam pembahasan figh. Sedangkan dalam figh sebagai disiplin ilmu pengetahuan adalah merupakan hasil penafsiran ajaran agama sesuai dengan realitas masyarakat. Sebagai sebuah produk penafsiran, ia tidak bisa dianggap sama dan sebangun dengan agama itu sendiri. Figh lebih tampak sebagai kesimpulan dari "cara baca" umat Islam terhadap fenomena kemasyarakatan. Tentu saja terdapat diferensiasi pemikiran mengenai hal tersebut, karena "pembacaan" atas realitas pastilah tidak sama akibat perbedaan perspektif yang digunakan dalam membidik realitas sosial untuk kemudian dikonfirmasikan pada syarî'at, baik karena alasan metodologis atau kecenderungan teologis maupun karena dilatarbelakangi oleh fakta sosial itu sendiri. Dengan metode legislasi atau penggalian hukum yang berbeda, anatara seorang mujtahid dengan mujtahid lain boleh jadi akan menghasilkan produk yang berlainan pula tanpa ada pihak yang absah untuk mengklaim metodenya sebagai yang paling otoritatif. Demikian pula keragaman aliran teologis yang tak terelakkan bakal ikut mempengaruhi warna-warninya yurisprudensi Islam. Sedangkan fakta sosial yang juga berbeda-beda antara satu lingkungan masyarakat dengan yang lainnya, secara tidak langsung akan turut menentukan pula pembentukan struktur nalar di antara 
para mujtahid53 yang memang hidup dalam situasi dan kondisi masyarakat yang berbeda54.

Pada gilirannya, perbedaan dalam "membaca" realitas tersebut menjadikan fiqh sangat variatif. Bahkan terkesan paradoks. Fenomena ini menjadi kekuatan sekaligus kelemahan figh. Di satu sisi, ia tampak sangat dinamis serta memiliki spektrum yang luas karena mampu mengatasi keberbahagiaan corak hidup manusia yang berdiam di segala penjuru. Di sisi lain, kekayaan kahazanah ini berpotensi menimbulkan polarisasi yang tajam di kalangan para pengikut madzhab.

Selain itu, polarisasi pemikiran boleh jadi juga disebabkan karena semenjak masa yang sangat dini dari sejarah Islam sudah terdapat perbedaan pendapat yang terjadi di kalangan para sahabat. Pada masa itu telah dikenal tradisi penafsiran yang lebih bersifat tekstual di satu pihak, serta tradisi penafsiran kontekstual di pihak lain, yang keduanya menampakkan diri dalam tradisi fiqh 'Alawi (dinisbatkan kepada Alî bin Abî Thâlib) dan Fiqh 'U mari (dinisbatkan kepad 'Umar bin Khaththâb). Dua tradisi pemikiran tersebut selanjutnya menimbulkan semcam "patronase" dalam sistem pemahaman keagamaan, yang semakin lama semakin luas55.

Harus diakui bahwa di dalam figh, fenomena tersebut sulit dihindari, sehingga kemudian melahirkan sebuah sistem jaringan guru dan murid (isnad) yang relatif ketat. Pembacaan atas realitas sosial, untuk dihadapkan dengan teks agama, biasanya secara setia didasarkan pada manhaj yang telah lazim digunakan dalam jaringan tersebut. Meski pada perkembanganya tidak mudah untuk mempertahankan kekakuan yang melekat padanya, dalam arti bahwa manhaj yang dipergunakan tidak selamanya cukup mampu untuk menampung gagasan baru di masa selanjutnya,

53 Lihat juga pemikiran John L. Esposito, Islam the Straight Path (New York: Oxford University Press, 1988), hlm. 118

54 Bahkan Imam Syafi'I sendiri sempat menimbulkan figh dengan corak yang berbeda, sehingga ada istilah qawl qadîm dan qawl jadîd berdasarkan realitas sosial yang berbeda antara ketika dia berada di Mesir dengan ketika dia berada di Baghdad (Irak).

55 A. Hasyim Muzadi, N ahdlatul U lama di Tengah A genda Persoalan Bangsa, (Jakarta: PT. Logos Wacana IImu, 1999), hlm. 128 
Moh. J azuli

penyikapan terhdap suatu kasus hukum dianjurkan agar tetap mengacu pada manhaj yang telah disepakati, betapa pun perbedaan hasil akhir kerap terjadi. Maka tidak aneh kalau pandangan madzhab Syâfi'î (pengikut al-Syâfi'î) dalam beberapa persolan berbeda dengan al-Syâfi'î sebagai pemilik madzhab. A plagi jika dikaitkan dengan sistem pemahaman lain yang juga membentuk madzhab sendiri56. Perbedaan yang muncul bukan saja memperlihatkan keragaman pendangan yang masih dapat ditarik sebuah garis yang sejajar, melainkan cukup banyak menyisakan kontradiksi atau polarisasi yang tidak mudah untuk dikompromikan. Kemudian sedikit demi sedikit, polarisasi pemikiran tersebut semakin luas dan menjangkau persoalanpersoalan yang kompleks. Hal itu dibuktikan bahwa sampai abad pertengahan, konon terdapat tak kurang dari tiga ratus madzhab fiqh dengan pengikut yang tersebar di berbagai wilayah.

Terlepas dari keragaman yang mungkin bisa dijadikan sebagai faktor penghambat upaya unifikasi, fenomena tersebut mengindikasikan bahwa perbedaan pemikiran yang terjadi sampai pada abad pertengahan dapat dipandang sebagai usaha sunguh-sungguh umat Islam untuk "menjaga" universalitas ajaran agamanya. Dalam hal itu, pilihan yang tersedia memang hanya dua: Pertama, membakukan agama sebagaimana yang tercantum dalam teks-teks suci, serta membiarkannya berjalan pada suatu garis penafsiran yang linier tanpa interpretasi ulang, meskipun ia bersentuhan dengan kompleksitas persoalan kemanusiaan, yang semuanya itu berarti menutup rapat-rapat pintu agama dari upaya kontekstualissasi yang lebih berkesadaran sejarah. Tentu saja alasan yang masih tersisa untuk membenarkan pilihan ini adalah kekhawatiran yang berlebihan bahwa reinterpretasi atau kontekstualisasi akan dapat menodai sakralitas agam, Kedua, melakukan dinamisasi atas ajaranajarannya yang tentu saja mentoleransi upaya interpretasi agama dalam rangka mencari titik relevansinya dengan kebutuhan zaman yang terus berkembang. Karena seandainya hal tersebut tidak dilakukan, maka konsep universalitas yang selalu

56 Tolak Imam Putera,"Pembaharuan Fikh di Mesir dari Kritik Formalisme Teks Menuju Kontestual isme" T ashwirul A fkar, No. 8 (2000), hlm. 41 
didengung-dengungkan Islam tidak akan mampu menjawab perubahan mengingat ketidakpastiannya untuk menghadapi halhal baru yang muncul belakangan 57 .

Oleh karena itu, ketika kembali kepada persoalan pemaknaan hadîts utama di atas, maka harus dipahami dan dirujukkan kepada sejarah tentang Persia dan Kisra. Sesungguhnya hadîts itu disabdakan oleh Nabi dalam konteks peristiwa tertentu, yaitu orang-orang Persia telah mengangkat anak perempuan Kisra sebagai raja mereka. Ibnu Hajar al'Asqalani menyebutkan bahwa hadîts itu merupakan bagian terakhir dari kisah Kisra yang merobek-robek surat Nabi saw kepadanya. Kemudian Kisra menyerahkan kekuasaannya kepada anakanya dan anaknya membunuhnya, kemudian anak itu membunuh saudara-saudaranya. Dan ketika anak itu meninggal, kekuasaan berpindah ke tangan anak perempuannya yang bernama Buran binti Syirawiyah bin Kisra. Maka hilang dan hancurlah kerajan mereka, sebagaimana yang didoakan oleh Nabi Muhammad saw58.

Al-Bukhâri telah meriwayatkan dua hadîts lainnya berkenaan dengan masalah Persia, sebagai berikut: Pertama, "diriwayatkan dari Ibnu A bbas ra: bahwa Rasulullah saw mengirimkan suratnya kepada Kisra melalui A bdullah bin Khudhafah al-Sahmi untuk memberikan kepada pemimpin Bahrain, kemudian pemimpin Bahrain mengantarkannya kepada Kisra. Ketika Kisra membca surat itu, dia merobek-robeknya, lalu saya menduga bahwa Sa'id bin Musayyab berkata:"Kemudian Rasulullah berdoa kepada Allah agar mereka dirobek-robek oleh Allah swt"59. Kedua, "sesungguhnya Rasulullah saw bersabda:" Kalau kaisar telah hancur, tidak akan ada kaisar sesudahnya. D emi diriku yang berada ditangan- $N$ ya hendaklah kalian menafkahkan perbendaharaan keduanya di jalan Allah swt" 60 .

Kesimpulannya, hadîts tersebut khusus berkenaan dengan orang Persia, dan hanya menyangkut masalah berita dan kabar

57 Muzadi, N ahdlatul U lama, hlm. 129

58 Ibnu Haiarar al-Asqalani, Fath al-Bâri Syarh Shahîh Bukhari, Juz VII (Beirut: Dâr al Fikr, t.th), hlm. 735

59 Lihat al-Bukhârî, Shahîh al-Bukhârî, Juz II, hlm. 722

60 Ibid., hlm. 531 
Moh. J azuli

gembira, serta tidak ada sangkut-pautnya dengan masalah hukum syarî'at.

Walaupun ada kaidah ushul figh yang mengatakan pelajaran itu harus diambil dari keumuman lafadznya dan bukan kekhususan sebabnya, sesungguhnya ada qarinah (konteks) yang menunjukkan kekhususan sebab hadîts tersebut, yaitu ayat alQur'ân yang mengisahkan tentang Bilqis, Ratu Saba' (surat alNaml (27): 28-44) yang memegang kekusaan kaumnya berdasarkan musyawarah. Dia bijak dan menguasai hukum sosial, kemudian dia dan kaumnya memperoleh kejayaan.

Ayat-ayat tersebut termasuk dalam syarî'at orang-orang sebelum kita sehingga mungkin telah dihapuskannya oleh sunnah Nabi. Karenanya sesungguhnya hadîts tersebut, sebagaimana yang kita sebutkan tidak memuat muatan hukum tetapi hanya membawa berita ketidakjayaan. Di samping itu sesungguhnya kompetensi tidak berkait dengan perbedaan syarî'at. Tetapi bergantung pada kemampuan perempuan dan akalnya. Ini merupakan fitrah dan sunnah dan bukan hukum yang telah terhapus. Kalau hadîts ini dianggap bersifat umum akan timbul kontradiksi antara al-Qur'ân dan Sunnah, dan itu tidak khusus berkenaan dengan kaum Persia dan ketidakmampuan mereka manarik diri dari kekuasaan perempuan.

Sebagian orang mempunyai asumsi bahwa pemberian kekuasaan terhadap perempuan bertentangan dengan dua kemaslahatan; kemaslahatan umat dan kemaslahatan keluarga. Adapun persoalan kekuasaan, telah ada landasan tempat berpijaknya fardu kifâyah, yang sifatnya tidak memberikan beban kewajiban kecuali yang sesuai dengan kemampuan seseorang. Sesungguhnya perempuan tidak boleh memegang kekuasaan, kecuali bila dia memiliki kompetensi untuk itu, sehingga memungkinkannya untuk mengemban amanat kekuasaan yang diberikan kepadanya, tanpa berbenturan dengan kemaslahatan umat dan keluarga. Sehubungan dengan masalah ini, persoalan kekuasaan kembali kepada pengcualian dan kekhususan yang dimiliki oleh seseorang karena kekuasaan merupakan salah satu bentuk fardu kifayah. Kesimpulannya, kekuasaan umum mengharapkan adanya suatu kompetensi khusus, dan 
sesungguhnya di antara perempuan ada yang memiliki kompetensi tersebut serta berhak untuk mengemban beban tanggungjawab fardu kifayah ini dan tidak usah peduli dengan pandangan yang menentangnya. Kalau kita berprasangka bahwa sedikit sekali perempuan yang sekaligus menangani tanggungjawab kekuaasaan dan tanggungjawab keluarganya karena sedikit sekali mereka yang dapat melakukannya dalam masyarakat Islam, hal itu tidak boleh dijadikan sebagai salah satu variabel yang berkaitan dengan lemahnya partisipasi perempuan dalam kegiatan sosial politik. Akan tetapi bagaimanapun menurut hemat penulis bahwa pandangan-pandangan para ulama yang memberikan batasan-batasan ruang gerak perempuan untuk ikut berkiprah di arena publik juga penting dijadikan bahan pertimbangan. Karena antar laki-laki dan perempuan sama-sama mempunyai hak serta kewajiban maasing-masing baik dalam urusan domistik keluarga maupun di luar keluarga. Hal itulah yang kemudian diharapkan jangan sampai terjadi tumpang-tindih hak dan kewajiban antara laki-laki dan perempuan.

Menurut hemat penulis bahwa sesungguhnya perbedaan pandangan itu disebabkan oleh pola pikir yang mereka kembangkan. Sekali lagi penulis ingin tegaskan bawha kelompok sriptualis selalu melihat syarî'ah sebagai aturan yang sudah baku dan bahkan final, sehingga tidak perlu lagi ada pemahaman dan pemaknaan lain yang bernuansa ijtihâdi sesuai dengan perkembangan ruang dan waktu. Keinginan untuk memuja teksteks (khususnya yang syar'î) telah mendarah daging dalam benak pikiran mereka. Kelompok itulah yang terkesan kurang kreatif, eksklusif, dan fanatis. Sedangkan kelompok substansialis selalu berusaha untuk melakukan pendekatan-pendekatan yang bijaksana terhadap syarî'ah khususnya masalah fiqh, sehingga ajaran Islam nampak terbuka, bebas dan tidak kaku berhadapan dengan persoalan modernitas. Mereka tidak semata-mata mengilustrasikan persoalan dengan teks, tapi di saat yang sama mereka mengangat rasionalitas sebagai neraca teks. Malahan dalam banyak kesempatan mereka mencoba mengetengahkan beberapa solusi alternatif terhadap kejumudan fiqh, sehingga 
Moh. J azuli

mereka pun harus mencoba melepaskan sekat-sekat untuk sampai ketujuan.

\section{Penutup}

Dari beberapa uraian di atas dapat disimpulkan bahwa: Pertama, corak pemikiran yang berbeda antara skriptualis dan substansialis dalam persepektif ideologis adalah disebabkan metode pemaknaan mereka terhadap teks ajaran juga berbeda. Kalau skriptualis, mereka meletakkan teks ajaran (termasuk figh) pada garis kemapanan dan menolak segala macam upaya para cendekiawan kontemporer yang telah merumuskan ijtihâd untuk membawa wacana fiqh kepada tatanan wacana bebas dan terbuka. Bahkan terkesan mereka ekslusif dalam merespon berbagai macam persoalan yang muncul dan menganggap semua teks ajaran (termasuk figh klasik) adalah teks suci yang tidak boleh direduksi dengan interpretasi apapun. Sedangkan substansialis, mereka selalu berusaha untuk melakukan pendekatan-pendekatan bijaksana dan moderat, khususnya dalam bidang figh. Landasan mereka adalah sebuah representasi pemikiran yang tepat pada waktunya. Sehingga dengan demikian, ajaran Islam akan nampak terbuka, bebas dan tidak kaku berhadapan dengan persoalan-persoalan modernitas.

Kedua, perbedaan pemikiran skriptualis dan substansialis dalam perspektif sosiologis juga disebabkan oleh paradigma yang berbeda terhadap fenomena sosial yang berkembang. Kalau skriptualis, melihat fenomena sosial sebagai realitas yang harus tunduk pada teks ajaran. A pabila terjadi paradoks antara realitas dengan teks ajaran, maka harus ada penaklukan realitas terhadap teks ajaran itu. Yang nampak adalah bahwa teks ajaran terkesan kaku dan kurang memberikan ruang gerak perbeadaan terhadap kompleksitas sosial yang terus berkembang. A khirnya, teks ajaran tidak semuanya dapat diterima dan sesuai dengan kondisi sosial tertentu. Sedangkan pemikiran substansialis adalah pemikiran yang senantiasa memahami dan menerima perkembangan realitas sosial dengan mempertimbangkan substansi dari teks ajaran. Sehingga dengan demikian teks ajaran akan selalu diterima untuk diaktualisasikan dan diaplikasikan sesuai dengan kondisi sosial tertentu. Karena pada hakekatnya substansi dari ajaran tersebut adalah mengandung nilainilai keuniversalan yang holistik dan dapat menjangkau seluruh 
lapisan sosial seiring dengan perkembangan budaya dan tuntutan modernitas. W allâh a'lam bi al-shawâb.

D aftar Pustaka:

Abdalla, Ulil Absar. "Hair Splitting Politics", Kompas, Senin, 14 Januari 2002.

Ahmed, Ishtiaq. "Abdullahi Ahmed An-Na'im on Constitutional and H uman Rights Issue," dalam Tore Lindholm and Karl Vogt (ed.), Islamic Law Reform and Human Rights: Challenges and Rejoinders, Oslo: Nordic Human Rights Publication, 1993.

A hmed, Khurshid. " The Nature of Islamic Resurgence," dalam John L. Esposito (ed.), Dinamika Kebangkitan Islam, Jakarta: Rajawali Press, 1987.

Alfian M., M. Alfan. "Genderisasi Demokrasi". Kompas, Senin, 14 Januari 2002.

Alhumani. "Islam di Indonesia dari Skriptualisme ke Substansialisme." Republika, 29 Juli 1999.

Arsyi, Sitrul et al., Satu A bad Annuqayah: Peran Pendidikan, Politik, dan Pengembangan M asyarakat. Sumenep: PP. Annuqayah GulukGuluk Sumenep, 2000.

An-Na'im, Abdullahi Ahmed, Toward an Islamic Reformation: Civil Liberties, Human Rights, and International law. New York: Syracuse University Press, 1990.

Asqalani, Ibn ㅂajar Al-. Fath al-Bâri Syarh Shahîh Bukhârî. Beirut: Dâr al Fikr, tt, juz VII.

Bahnasawi, Salim Ali. W awancara Sistem Politik Islam. Jakarta: Pustaka al Kautsar, 1997.

Barton, Greg. "Neo-Modernism: A Vital Synthesis of Tradisionalist and Modernist Islamic Thought in Indonesia."Studia Islamika, Number 3 (1995).

Bodgan, Robert C. dan Biklen, Knopp. Qualitative Research for Education, An Introduction to Theory and M ethod. Boston: Allyand Boston, Inc., 1982. 
Moh. J azuli

Bruinessen, Martin Van. NU Tradisi, Relasi-Relasi Kuasa, Pencaharian W acana Baru. Yogyakarta: LKIS Yogyakarta, 1994.

Bukhârî, al- Sahîh al-Bukhârî, Juz III. Beyrut; Dâr al-Fikr, 1990.

Bush, Robbin L. A mbigu-A mbigu di Balik Republik NU dalam Geger di Republik N U . Jakarta: PT. Kompas Media Nusantara, 1999.

Denzin, Norman K. dan Lincholn, Yovanna S. (ed.). Handbooks of Q ualitative R esearch. London: Sage Publication, 1994.

Dessouki, Ali E. Hilal. Encyclopedia of Religion, vol. 12. Baltimore: John Hopkins University Press, 1981.

Engineer, A sghar A li. H ak-H ak Perempuan dalam Islam. Jakarta: LSPPA, 1994.

Esposito, John L. dan Voll, John O. Islam and Democracy. Oxford: Oxford University Press, 1996

Esposito, John L. Islam the Straight Path. New York: Oxford University Press, 1996.

Fakih, Mansour, et al. M embincang Feminisme D iskurus G ender Perspektif Islam. Surabaya: Risalah Gusti, 1996.

Feillard, Andree. NU dan N egara dalam GU SDUR, NU dan M asyarakat Sipil. Yogyakarta: LKIS Yogyakarta, 1997.

-. N U vis a vis N egara. Yogyakarta: LKIS Yogyakarta, 1999

Garaudy, Roger. Islam Fundamentalis dan Fundamentalis Lainnya. Bandung: Pustaka, 1993

Hamim, Thoha. "Islam dan Hubungan antar Umat Beragama," Forma, Edisi XXVI Th. XV (2000)

Ja'far, Muhammad Anis Qasim. Perempuan dan Kekuasaan, terj. Irwan Kurniawan dan Abu Muhammad. Bandung: Zaman, 1998

Jalil, Matori Abdul. "PKB dan Inklusivisme Islam," dalam Marzuki Wahid, et al. (ed)., Geger di "Republik" NU; Perebutan Wacana, Tafsir Sejarah, Tafsiran M akna, Jakarta: Kerjasama Kompas dan Lakspesdam NU Jakarta, 1999. 
Kahmad, Dadang. Sosiologi A gama. Bandung: PT. Remaja Rosdakarya, 2000

Madjid, Nurcholis. Islam Agama Kemanusiaan. Jakarta: Paramadina, 1995

Mansurnoor, lik Arifin. Islam in an Indonesian World U lama of M adura. Yoyakarta: Gajah Mada University Press, 1990

Mernissi, Fatimah dan Hasan, Riffat. Setara di H adapan Allah, Relasi laki-Laki dan Perempuan Dalam Tradisi Islam Pasca Patriarkhi. Yogyakarta: LSPPA, 1995

Mernissi, Fatimah. Menengok Kontroversi Peran Wanita dalam Politik. Surabaya: Dunia Ilmu, 1997

Moleong, Lexy J. M etodologi Penelitian Kualitatif. Bandung: Rosdakarya, 1994

Musa, Ali Maschan. Kyai dan Politik. Surabaya: Bina IImu, 1999

Muzadi, A. Hasyim. Nahdlatul Ulama di Tengah Agenda Persoalan Bangsa, Jakarta: PT. Logos Wacana IImu, 1999

Nasution, S., M etode Penelitian N aturalistik-Kual itatif. Bandung: Tarsito, 1988

Putera, Tolak Imam. "Pembaharuan Fikih di Mesir; Dari Kritik Formalisme Teks Menuju kontekstualisasi". Tashwirul A fkar, No. 8 (2000)

Rahman, Fazlur. Islam. Chicago: University of Chicago Press, 1979

Rumadi. "Islam Liberal "Plus"=Post-Tradisionalisme Islam". Kompas, 23 Nopember 2001.

Thaha, Zainal Arifin dan Mustafa, M. Aman. Membangun Budaya Kerakyatan: Kepemimpinan Gus Dur dan Gerakan Sosial NU. Yogyakarta: Titian Ilahi Press, 1997

Thalib, Muhammad. 17 A lasan M embenarkan Wanita M enjadi Pemimpin dan A nalisisnya. Bandung: I rsyad Baitus Salam, 2001

Uhlin, Andres. Democracy and Diffusion: Transnational Lesson-D rawing A mong Indonesian Pro-D emocracy A ctors. Sweden: Lund Political Studies 67, 1995 
Moh. J azuli

Wahid, Marzuki, et al. Dinamika N U Perjalanan Sosial. Jakarta: PT. Kompas Media Nusantara, 1999

Watt, Montgomery. Islamic Philosophy and Theology. Edinburgh: Edinburgh univerity Press, 1972.

Zainuddin, M. “Reposisi NU ke Depan”, Jawa P os, 11 Juni 2001 